\title{
Newspaper Readership in Lesotho
}

\author{
Makhetha L. S and Thamae R. I
}

\begin{abstract}
Independent newspapers have become the backbone of the publishing industry and some are among the most widely distributed newspapers within the country. Despite this fact, the readership experience of these newspapers and their impact on democratic process are much less well documented. The objective of this paper is therefore to assess the readership of the main local independent newspapers in Lesotho. This paper uses the survey dataset collected from 497 selected individuals who read the main independent newspapers in seven districts of Lesotho. Although the findings show that readership intensity is relatively low in Lesotho, the respondents indicated that the newspapers are however of good quality, and have contributed positively to democratic process in Lesotho. Results further reveal that enthusiastic readers of local independent newspapers are likely to be those who are politically inclined and those who rely on newspapers for information.
\end{abstract}

Keywords - Readership, Independent Newspapers, Lesotho.

\section{INTRODUCTION}

Almost in every part of the world, there are people who read newspapers. This is because newspapers, like other forms of media, play a major role in disseminating information and knowledge. They reveal plans and policies of governments and corporations. They are also important medium of advertisement for businesses and industries through brand promotion. Furthermore, newspapers are central to economic and democratic development, cultural dialogue and good governance as they promote current affairs debates on such issues. For example, Stromberg (2015) argues that unbiased media, including newspapers, can improve political accountability by providing information that makes votes to be more responsive to the quality of policy outcomes. This function is crucial, especially in developing countries, where lack of development is often attributed to corruption and misuse of public funds by the government.

In Lesotho, independent newspapers have become the backbone of the publishing industry and independent newspapers are among the most widely distributed newspapers within the country. Despite the widespread interest in understanding newspaper readership, research on independent newspapers readership in Lesotho at its crux is sparse. Thus, this raises the following questions: Who reads local newspapers and why do they read them? What are the perceptions regarding the quality of these publications and their effectiveness in

Makhetha L. S and Thamae R. I, Department of Economics, National University of Lesotho. advertising? What are the effects of these newspapers on Lesotho's democratic process? Understanding these questions matters for two reasons. First, given the dynamic and radical nature of the media environment, any change in the readership pattern may have critical implications towards the future competitiveness and survival of these publications. Second, the perception about the role of newspapers in Lesotho's democratic process may offer some insights on the degree of media captured by the government, especially in a context where a considerable share of the newspapers' income comes from government-related advertising (see Di Tella and Franceschelli, 2009).

The objective of this paper is therefore to assess the readership of the main local independent newspapers in Lesotho. The study specifically seeks to understand who are reading these newspapers and why they read them. It also aims to determine the perception regarding the quality of these publications and their effectiveness in advertising as well as the effects of these newspapers on Lesotho's democratic process. The remainder of this paper is structured as follows: section II reviews the literature on newspaper readership and overall role of media in advertising and politics; section III provides a brief background on Lesotho's newspaper industry while section IV outlines the methodology; section $\mathrm{V}$ presents the results and their analysis and section VI concludes the paper.

\section{LITERATURE REVIEW}

\section{A. Newspaper Readership}

The concept of readership is usually associated with all sorts of periodicals including but not limited to newspapers and magazines. It is generally defined as the number (or type) of people who read a particular printed periodicals. Alternatively, some authors (see Patrick and Melchizedec, 2014; Olofin, 2012) define readership as part of the general public interested in a source of information, entertainment or advertising. Since readership has helped people to gain access to the latest news happening domestically and internationally, newspaper readership has been part of people's habit for decades. Readership is also of utmost importance because it determines the circulation figures of newspapers, which attract advertisers who want to reach their target market. Newspapers also stand out in publishing strong opinions and complying analysis. Nevertheless, it is not everyone that is interested in the same section of the newspaper or reads all sections. For example, well informed individuals and/or business people are more concerned about current affairs and/or business sections since they have implications on the stability of an economy and future investment opportunities. Conversely, young people read 
newspapers because they present them with entertainment while sports fanatics are interested at the section of newspapers that provides them with sports news. According to Maier et al. (2014), newspaper readership is more prevalent in older age groups but less common among younger generations. This is plausible given much interest of young people on social media and their relatively low purchasing power, which makes them consider buying newspapers expensive.

\section{B. Media and Advertising}

Even though the primary role of the media is to provide information, this only boosts its ratings for audiences while the major aim is to sell audiences to the advertisers for profit. Bagdikian (1990) supports this view by making remarks that market journalism gathers an audience not to inform it, but to sell it to advertisers. Therefore, companies rely on the media to market their products and increase sales. In line with Hirschman and Thompson (1997), media and advertising has a mutually beneficial relation in which the media improves the effectiveness of advertising by representing certain product or brand collections as more desirable than others. Furthermore, the media that knows how to target the right audience with a high circulation figure is a great opportunity for advertisers to reach their target market. This may result in huge sums of money to the media that will enhance its channels and quality.

However, given that the media's dependence on advertising could result in being controlled by the demands of advertisers, the balance between advertising and being the supplier of information remains a critical issue. Interestingly, literature indicates that if readers perceive adverts not appealing, then newspaper will have less advertising than what maximizes advertising revenue thus advertising has less of an impact on newspaper readership (see Sonnac, 2000; Depken and Wilson, 2004). One might be inclined to expect that the opposite would be true when adverts are perceived to be appealing. However, Kind et al. (2007) find that the incentive to moderate content is weakened also if readers like advertising. The authors explain that the reason for this is that the newspapers then choose a higher level of advertising than what maximizes advertising receipts. This strengthens the newspapers' incentive to differentiate their profile in the same way as when readers dislike adverts.

\section{Media, Politics and Democracy}

Media also has a well-built influence in a democratic world since it supplies useful information to rational voters. Curran (2002) indicates that media acts as an agent between the government and people by reporting news for public scrutiny and discussion, and this keeps people actively involved in society and politics. This information from media can make votes more responsive to the quality of policy outcomes, leading to enhanced political accountability (see Stromberg, 2015). For instance, when in office, politicians may not care much about accountability. However, when media re-evaluates their terms, voters are able to consider whether they want the same politicians to hold office with their past path record during a political change. Therefore, this kind of an independent media that keeps an eye on those in power and distribute truthful information to voters can be an effective check on corruption, which is prevalent in the public service of most developing countries. Holmes (1991) indicates that the role of media in deepening democracy, particularly where institutions are weak, do not live up to the ideal. They are hobbled by stringent laws, monopolistic ownership, and to some extent, the threat of brute force.

Consequently, Waldahl (2008) argues that failure of media to provide relevant and credible information can either make voters' political choices be based on insufficient grounds or make them fail to participate for want of knowledge. This situation may occur where there is media capture by certain interested groups. For instance, Stromberg (2015) contends that in countries where silencing the media is less costly, it will be easily captured by various groups such as politicians, businessmen and other advertisers. This will consequently minimise the effects of media on democratic process. On the other hand, media may force politicians to focus on issues that are not of great importance, hence leading to policy biases. Eventually, voters with little access to media will be ignored and their issues will be regarded as less newsworthy by the journalists.

\section{LESOTHO'S NEWSPAPER INDUSTRY}

According to Fako (2000), the Lesotho's press history is deeply rooted in the institution of the church as the missionaries sought to educate and civilise the Basotho. For instance, Paris Evangelical Missionary Society - the first missionaries to settle in Lesotho, established the first Sesotho weekly newspaper named Leselinyana la Lesotho in 1863. It was followed by three more newspapers published by the Roman Catholic missionaries, namely: Naledi ea Lesotho in 1904, Mochochonono in 1911, and Basutoland news in 1927. The Catholic missionaries also published Moeletsi oa Basotho in 1933, which went on to become one of the most widely read newspapers at that time.

Alternatively, Lesotho government established Lesotho Information Service (LIS) in 1963 with the aim of providing news and information to the public. During that time, LIS published its first newspaper called Basutoland Times, which was later named Lesotho Times following the independence in 1966. In 1968, LIS replaced this newspaper with Koena and Molia, but they only survived for few years. About two decades later, the government began publishing other two newspapers Lentsoe la Basotho in 1986 and Lesotho Today in 1987, and these newspapers survived till today.

On the side of independent newspapers, the main players have been Public Eye (published since 1997), Mosotho (published since 2003), Lesotho Times (published since 2008), Sunday Express (published since 2010) and The Post (published since 2014). All these newspapers are published on weekly basis and in English, except Mosotho, which is published in local language - Sesotho. Strong competition also exists among these newspapers as they strive to achieve the highest 
circulation and gather as much advertising revenue as possible.

\section{Methods And DATA}

\section{A. Data Collection}

This study uses the survey dataset collected from 497 selected individuals who read independent newspapers in seven districts of Lesotho, namely: Maseru, Berea, Leribe, Butha-Buthe, Mafeteng, Mohale's Hoek and Quthing; as opposed to a total of ten districts. These districts are chosen for two reasons. The first reason being that they are good representatives of the central (Maseru), northern (Berea, Leribe and Butha-Buthe) and southern (Mafeteng, Mohale's Hoek and Quthing) regions where there is a considerable circulation of local independent newspapers. The second reason arises from financial constraints that limited the survey to be done under only seven districts. The data were collected on the 12th, 19th and 26th of March 2016 using a semi-structured questionnaire and some of the close-ended questions were based on 5-point Likert-type scale ranging from "very poor" to "very good" or "strongly disagree" to "strongly agree". The passive sampling was done in the main towns of those districts and questionnaires were distributed among the individuals who were present in those towns during the time of interview. Questionnaires' distribution was in proportion to each district newspaper circulation. Data are used to determine the readership intensity, perceived quality of local newspapers and attitude towards advertising. It also provides the perceptions about the effects of newspapers on Lesotho's democratic process, freedom to criticise the government publicly as well as reliance on newspapers as source of information.

\section{B. Data Description}

Table 1 gives a summary of survey data. It shows that out of 497 respondents, $46 \%$ were from the central region (or Maseru), $33 \%$ were from the northern region (with 20\% from Leribe, $8 \%$ from Butha-Buthe and $5 \%$ from Berea) and $21 \%$ were from the southern region (Mafeteng, Mohale's Hoek and Quthing, with $7 \%$ each). The respondents were predominantly younger ( $75 \%$ is less than 40 years), employed (66\%), male (64\%), having tertiary education (49\%), married (48\%) and coming from the middle-low income household (31\%).

TABLE I: DESCRIPTION OF READERSHIP SURVEY DATA (SAMPLE SIZE $=497$ )

\begin{tabular}{|l|l|r|r|}
\hline Variables & Maseru & \multicolumn{2}{|c|}{ Number of Participants (\% of total) } \\
\hline Region & Berea & 229 & $(46 \%)$ \\
\hline & Leribe & 25 & $(5 \%)$ \\
\hline & Butha-Buthe & 101 & $(20 \%)$ \\
\hline & Mafeteng & 41 & $(8 \%)$ \\
\hline & Mohale's Hoek & 32 & $(7 \%)$ \\
\hline & Quthing & 35 & $(7 \%)$ \\
\hline Sex & Female & 34 & $(7 \%)$ \\
\hline & Male & 180 & $(36 \%)$ \\
\hline Age & Younger than 30 & 317 & $(64 \%)$ \\
\hline & 30 or older & 233 & $(47 \%)$ \\
\hline Marital Status & Single & 264 & $(53 \%)$ \\
\hline & Married & 211 & $(42 \%)$ \\
\hline & Separated & 239 & $(48 \%)$ \\
\hline & Divorced & 10 & $(2 \%)$ \\
\hline & Widowed & 19 & $(4 \%)$ \\
\hline Education & None & 18 & $(4 \%)$ \\
\hline & Primary & 5 & $(1 \%)$ \\
\hline & Secondary & 31 & $(6 \%)$ \\
\hline & Tertiary & 199 & $(40 \%)$ \\
\hline & Vocational & 245 & $(49 \%)$ \\
\hline Employment & Employed & 17 & $(4 \%)$ \\
\hline & Not employed & 328 & $(66 \%)$ \\
\hline Household Income & Less than M2000 & 169 & $(34 \%)$ \\
\hline & Between M2000 and M5000 & 133 & $(27 \%)$ \\
\hline & Above M5000 & 152 & $(30 \%)$ \\
\hline & Undisclosed & 203 & $(41 \%)$ \\
\hline & & 9 & $(2 \%)$ \\
\hline
\end{tabular}

\section{SuRVEy RESUlts AND Discussions}

The study employs the mean responses, standard deviations and correlations to assess the readership intensity of the main local independent newspapers in Lesotho. The study specifically seeks to understand who reads local independent newspapers and why they read them. It also aims to assess the perception of the respondents regarding the quality of these publications and their effectiveness in advertising as well as the effectiveness of these newspapers on Lesotho's democratic process and governance. To test for reliability of the results, Cronbach's alpha (a) test was used. Cronbach's alpha is a coefficient of internal consistency. It is commonly used as an estimate of the reliability of a psychometric test for a sample of examinees. Given the exploratory nature of the research, $a=0.6$ was chosen as the cut-off point for reliability test. Even though 0.6 is considered relatively low, Manerikar and Manerikar (2015) however suggest that it is still acceptable. 
TABLE II: READERSHIP INTENSITY, PERCEIVED QUALITY AND ATTITUDE TOWARDS ADVERTISING

\begin{tabular}{|c|c|}
\hline Study Variables & Mean Responses \\
\hline Readership intensity & $2.48(S D=0.04 ; a=0.60)$ \\
\hline Reading frequency $^{1}$ & $2.46(S D=0.04)$ \\
\hline Number of issues read (of last four weeks) & $1.38(S D=0.05)$ \\
\hline Minutes reading $^{2}$ & $2.59(S D=0.06)$ \\
\hline $\begin{array}{l}\text { Perceived quality } \\
\text { Reliance on newspapers as a source of information }\end{array}$ & $\begin{array}{l}4.04(S D=0.03) \\
3.62(S D=0.05)\end{array}$ \\
\hline Attitudes toward advertising $^{4}$ & $3.63(S D=0.04, a=0.64)$ \\
\hline Look at adverts & $3.69(S D=0.05)$ \\
\hline Like inserts & $3.57(S D=0.05)$ \\
\hline
\end{tabular}

Table 2 highlights that newspaper readership intensity is generally low in Lesotho. This is suggested by the aggregate readership intensity mean response of 2.48 ( $\mathrm{SD}=0.04$; $\mathrm{a}=$ 0.60). When converted into Likert-type scale, the mean response of $2.46(\mathrm{SD}=0.04)$ for reading frequency and 1.38 $(\mathrm{SD}=0.05)$ for the number of issues read can be translated to indicate that the respondents 'sometimes' read local independent newspapers and had read at least one out of the last four issues, respectively. Similarly, the mean responses of 2.59, for minutes reading, when converted into Likert-type scale, imply that on average respondents spend about $30-45$ minutes reading the local independent newspapers. Interestingly, Lauf (2001) shows that low readership intensity of independent (paid) newspapers may be due to existence of free local newspapers. That is, there could be an extent to which paid independent newspapers and free local newspapers are substitutes. Therefore this could suggest that either respondents are not reading independent newspapers intensively or they may be reading more of free local newspapers. This substitution effect was observed by Lauf (2001) and Peiser (2000) who also show that the readership of paid newspapers is relatively low while readership of free newspapers is booming in the Western Europe and United States.

The results from table 2 on perceived quality, with a mean response of 4.04 ( $\mathrm{SD}=0.03)$ suggest that the respondents perceive the local independent newspapers to provide good quality information. Given this relatively high mean response of the perceived quality, one would expect the reliance on newspapers as a source of information to be high. Conversely, the mean score for reliance on newspapers as a source of information is $3.62(\mathrm{SD}=0.05)$. This suggests that, instead of respondents 'strongly agreeing' that they rely on independent newspapers as source of information, rather on average they just 'agree'. This outcome is likely to be influenced by other sources of information such as radios and televisions, thus suggesting that newspapers could be viewed as complements to sources of information. Nevertheless, Gibbons (2014) argues that the quality of newspapers plays a crucial role in its rate of circulation. When it comes to participants' attitudes towards advertising, although the mean score of $3.63(\mathrm{SD}=0.04, \mathrm{a}=$ 0.64 ) is above the middle, the results indicate that participants do not rely entirely on these local independent newspapers as the only forms of advertising. However, participants generally value the adverts as well as the inserts that come with the newspapers. In line with Hirschman and Thompson (1997), adverts and inserts have potential to represent certain product or brand collections as more desirable.

Table 3 reports the results on participants' responses regarding political participation, freedom to criticise the government and their perceived role of newspapers' in democratic process. The findings indicate that participants moderately agree that the idea of participating in politics is appealing to them. This is shown by a mean response of 3.49 $(\mathrm{SD}=0.06)$. Furthermore, the results show that participants almost 'strongly agree' that everyone should be given a freedom to criticize the government publicly, with mean response of 4.17 $(\mathrm{SD}=0.05)$. This implies that majority of participants have more pro-democratic and liberal attitudes that appreciate the public criticism of the government, seeing it as an essential aspect of free polity rather than as disrespect towards the authority. The participants also seem to agree that local independent newspapers have made a contribution towards Lesotho's democratic process. This is indicated by the overall mean response of $3.69(\mathrm{SD}=0.03, \mathrm{a}=0.68)$. This implies that participants moderately agree that local independent newspapers have contributed positively in shaping the country's democratic process and they are unbiased when reporting about politics as shown by the mean responses of $3.85(\mathrm{SD}=0.04)$ and 3.64 ( $\mathrm{SD}=0.05)$, respectively. In addition, the participants moderately agree that there is fair coverage of all political parties during elections and the independent newspapers are effective in revealing corruption in government as given by the mean responses of $3.69(\mathrm{SD}=0.05)$ and $3.59(\mathrm{SD}=0.03)$, respectively.

\footnotetext{
${ }^{1}$ Scale of reading frequency ranges from 1 (never) to 5 (very often).

${ }^{2}$ Scale of minutes spent on each newspaper ranges from 1 (less than 15 minutes) to 5 (more than 60 minutes).

${ }^{3}$ Scale of quality of information ranges from 1 (very poor) to 5 (very good).

${ }^{4}$ Scale of looking for adverts or inserts in newspapers ranges from 1 (strongly disagree) to 5 (strongly agree).
} 
TABLE III: POlitical PARTICIPATION, FREEDOM TO CRITICISE THE GOVERNMENT AND DEMOCRATIC PROCESS

\begin{tabular}{|l|c|}
\hline Study Variables $^{5}$ & Mean Responses \\
\hline & \\
\hline Political participation & $3.49(S D=0.06)$ \\
\hline Freedom to criticise government publicly & $4.17(S D=0.05)$ \\
\hline & $3.69(S D=0.03, a=0.68)$ \\
\hline Perceived role in democratic process & $3.85(S D=0.04)$ \\
\hline Positive contribution in democratic process & $3.64(S D=0.05)$ \\
\hline Unbiased when reporting about politics & $3.69(S D=0.05)$ \\
\hline Fair coverage of parties during elections & $3.59(S D=0.03)$ \\
\hline Effective in revealing corruption in government & \\
\hline
\end{tabular}

The observations on the newspapers' role in democratic process are in line with that of Basley et al. (2001) who emphasize that media plays a key role in enabling citizens to monitor the actions of incumbent governments and use that information in their voting decisions. Moyers (1993) further postulates that mass media are fourth branch of government because of the power they wield and the oversight function they exercise. Therefore, the involvement of independent newspapers by reporting about politics could lead to the governments that are more accountable and responsive to their citizens' needs. Again, in line with Liberal Pluralists Theory, (see Galston, 2002) press needs to be free and unencumbered by government or legislative oversight. It also needs to be the watchdog of the government and inform the polity of government policies while supporting the entrenchment of democracy.

The Pearson correlations are used to assess the relationships between readership and other variables. These correlation test results are able to set out who are the readers of independent newspapers and determine why they read these newspapers even though correlation test results show very low correlation between readership intensity and all other variables of interest. TABLE IV: PEARSON CORRELATION TEST

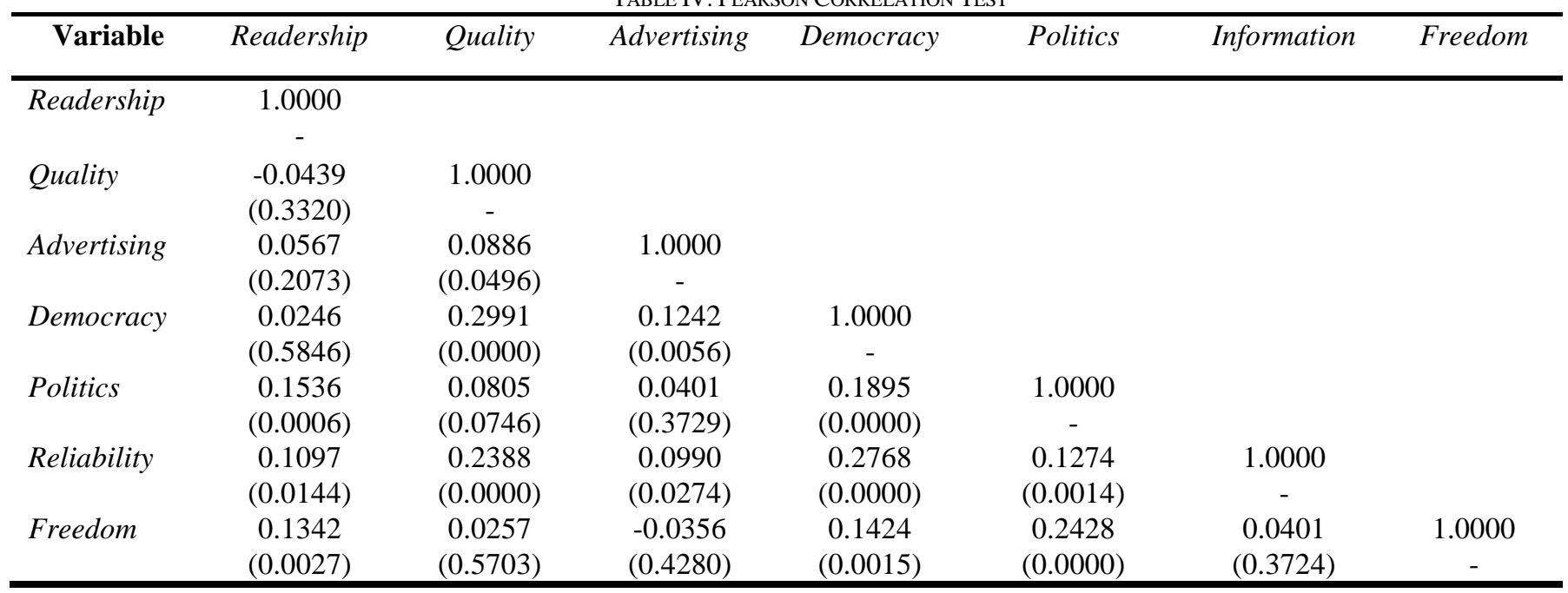

Note: p-values are in parenthesis.

Even though Table 2 suggests that the respondents perceive the local independent newspaper to be of good quality, conversely correlation results in Table 4 indicates that newspapers quality $(\mathrm{p}=0.3320)$ is insignificant in explaining readership intensity. Additionally, advertising $(p=0.2073)$ and democratic process $(p=0.5846)$ also seem to be insignificant in explaining readership intensity. However, Table 3 has conversely shown that local independent newspapers have moderately played a role in enhancing democratic process in Lesotho.

Interestingly, correlation results show significant positive correlation between readership intensity and political participation $(\mathrm{r}=0.1536 ; \mathrm{p}=0.0006)$; information reliability $(\mathrm{r}$ $=0.1097 ; \mathrm{p}=0.0144)$; and freedom to criticize the government publicly $(r=1342 ; p=0.0027)$. These results imply that avid local independent newspapers' readers are not just those who rely on newspapers for information, but also those who are political inclined as well as those who believe that everyone should be given the freedom to criticize the government public.

\section{CONCLUSION AND RECOMMENDATIONS}

The main objective of this study was to assess the readership of the leading local independent newspapers in Lesotho. The study specifically aimed to understand who are reading these newspapers and why they read them. It also intended to determine the perception regarding the quality of these publications and their effectiveness in advertising as well as the

\footnotetext{
${ }^{5}$ Scale ranges from 1 (strongly disagree) to 5 (strongly agree) for all variables.
} 
effects of these newspapers on Lesotho's democratic process. The following key findings were therefore obtained from the analysis of the survey data collected from 497 individuals who read newspapers in seven districts of Lesotho. Firstly, newspaper readership is relatively low in Lesotho and this could be due to existence of competing free local newspapers. Secondly, even though respondents perceive local independent newspaper to be of high quality, correlation results show that newspapers quality is insignificant in explaining readership intensity. Finally, the results indicate that avid independent newspaper readers in Lesotho are not only those who rely on independent newspapers as source of information but also those who are politically inclined as well as those who believe that everyone should be given freedom to criticize the government publicly. These are people who have political and liberal attitudes that appreciate the politics and constructive public criticism of the government. Therefore in order to increase independent newspaper readership intensity and circulation, it is of utmost importance to identify the prime target. As the results indicated, the avid readers of local independent newspapers in Lesotho are those who are politically inclined and those that believe that everyone should be given freedom to criticize the government publicly; therefore local independent newspaper could put more emphasis on politically related issues and perhaps add a section that gives the public opinions about government service conveyance.

\section{REFERENCES}

[1] Adams, S. (2009). "Can foreign direct investment (FDI) help to promote growth in Africa?" African Journal of Business Management, 3(5): 178-183.

[2] Bagdikian, B. (1990), The Media Monopoly, Beacon Press, Boston, MA.

[3] Basley T., Burgess R. and Prat A. (2001). "The Political Agency, Government Responsiveness and the Role of Media", European Economic Review, 45(4-6), 629-40. https://doi.org/10.1016/S0014-2921(01)00133-7

[4] Curran, J. (2002), Media and Power, Psychology Press, London, Routledge.

[5] Depken II C. A. and Wilson D. P. (2004). Is Advertising Good or Bad? Evidence from U.S. Magazine Subscriptions. Journal of Business 77 (2004) S61-S80. https://doi.org/10.1086/381519

[6] Di Tella, R. and Franceschelli, I. (2009), Government Advertising and Media Coverage of Corruption Scandals, NBERWorking Paper 15402.

[7] Fako, T. E. (2000), Media Integration in Lesotho: A Comparative Analysis of the On-line Press and Print Press - A Case Study of Mopheme (The Survivor) Weekly Newspaper, Master's Degree Dissertation, University of Natal, Durban.

[8] Galston W. A. (2002). The Practice of Liberal Pluralism: The Implications for Value Pluralism for Political Theory and Practice (New York: Cambridge University Press). https://doi.org/10.1017/CBO9780511613579

[9] Gibbons M. (2014). Newspaper Quality, Content and Competition in New Zealand. Pacific Journalism Review 20(1) 181. https://doi.org/10.24135/pjr.v20i1.193

[10] Hirschman, E.C. and Thompson, C.J. (1997), "Why Media Matter: Toward a Richer Understanding of Consumers Relationship with Advertising and Mass Media", Journal of Advertising, 26(1): 43-60. https://doi.org/10.1080/00913367.1997.10673517

[11] Holmes S. (1991). Liberal Constraints on Private Power? In Judith Lichtenberg (ed). Democracy on the Mass Media, Cambridge University Press, pp $21-65$.

[12] Kind J.H., Koethenbuerger M. and Schejelderup G. (2007). Advertising and Newspaper Differentiation: On the Role of Readers' Advertising Tastes. Working Paper
[13] Lauf, E. (2001). The vanishing young reader. Socio-demographic determinants of newspaper use as a source of political information in Europe, 1980-1998. European Journal of Communication, 16(2), 233-243. https://doi.org/10.1177/0267323101016002005

[14] Maier, G.T., O'Neil, N.B. and Fritz, J.M.H. (2014), "Who Reads Catholic Newspapers? Exploring Readership in a Changing Industry" Journal of Media and Religion, 13(3): 153-169. https://doi.org/10.1080/15348423.2014.938974

[15] Manerikar V. and Manerika M. (2015), Cronbach Alpha. A Peer Revised Journal. aWEshkar vol.XIX, Issue 1

[16] Moyers B. (1993). Overcoming Civic Literacy in Media Reader: Perspectives on Mass Media Industries, Effects and Issues. 2nd Edition, Belmont: Wadworth Publishing Company. Newspaper Research Journal, 21(2), 11-23.

[17] Olofin A. (2012). Newspaper Readership in the Civil Service: Case Study of Ekiti State Civil Servants. Online Journal of African Affairs, 1 2012.

[18] Patrick U. and Melchizedec Y. (2014). Assesment of Pattern of Editorial Readership in Nigerian Newspapers, Kogistate University. Journal of Mass Communication, 3, 2014,143.

[19] Peiser, W. (2000). Cohort replacement and the downward trend in newspaper readership.

[20] Sonnac N. (2000). Readers' Attitude Towards Press Advertising: Are They Ad-lovers or Ad-averse. Journal of Media Economics 13 (2000) 249-259. https://doi.org/10.1207/S15327736ME1304_ 4

[21] Stromberg, D. (2015), Media and Politics, CEPR Discussion Papers, No. 10426.

[22] Waldahl, R. (2008), "Politics and Persuasion: Media Coverage of Zimbabwe's 2000 Election", The Dyke: 9

[23] Zaller J. (1999). "A Theory of Media Politics." How the Interests of Politicians, Journalists and Citizens Shape the News. University of Chicago Press. 